\title{
ФІЗІОЛОГІЧНИЙ СТАН РОСЛИН, ПРОДУКТИВНІСТЬ ТА ЛЕЖКІСТЬ ЧАСНИКУ ОЗИМОГО ЗА ОБПРИСКУВАННЯ ОРГАНІЧНИМИ КИСЛОТАМИ
}

\author{
Яценко В. В.
}

\section{ВСТУП}

Важливе завдання сучасної фітофізіології - розроблення методів i технологій, які б забезпечили рослину можливостями для більш повного використання ii біологічного потенціалу для інтенсифікації синтезу асимілянтів та спрямування їх до господарсько цінних тканин і органів.

Однією 3 важливих цілей сучасного сільського господарства $\epsilon$ отримання продуктів із високим вмістом вітамінів. Продуктивність рослин залежить від умов навколишнього середовища. Вплив абіотичних чинників (дефіцит вологи, висока/низька i нестабільна температура повітря) є головним обмежуючим чинником в овочівництві в умовах континентального клімату, i тому $\epsilon$ постійна проблема підвищення стресостійкості овочевих рослин. Однією $з$ можливостей поліпшити стресостійкість вирощуваних культур є органічні кислоти, які мають прямий чи опосередкований вплив на фізіологічні процеси. Крім того, органічні кислоти відомі як біостимулятори, які позитивно впливають на ріст рослин, урожай і значно зменшують вплив стресових чинників на рослини, спричинений абіотичними факторами $1,2,3$.

Перспективний напрям регуляції ростових процесів - застосування нативних фітогормонів та синтетичних регуляторів росту - аналогів або модифікаторів дії фітогормонів. Із практичною метою широко застосовують рістстимулювальні гіберелінові препарати ${ }^{4,5,6}$, а також їх

\footnotetext{
${ }^{1}$ El-Shabasi M.S.S., Mohamed S.M.A., Mahfouz S.A. Effect of foliar spray with some amino acids on growth, yield and chemical composition of garlic plants. Proc. the $6^{\text {th }}$ Arabian Conference for Horticulture, March 20-22, Faculty of Agric., Suez Canal University, Ismailia, Egypt, 2005. P. 369.

${ }^{2}$ Kowalczyk K., Zielony T. Effect of aminoplant and asahi on yield and quality of lettuce grown on rockwool. Proc. Conf. of Biostimulators in Modern Agriculture, 7-8 Febuary, Warsaw, Poland 2008. P. 124.

${ }^{3}$ Abd El-Aal F.S., Shaheen A.M., Ahmed A.A., Mahmoud R. Effect of foliar application of urea and amino acids mixtures as antioxidants on the growth and yield and characteristics of squash. Res J Agric Biol Sci. 2010. № 6(5). P. 587.

${ }^{4}$ Ribeiro D.M., Araújo W.L., Fernie A.R., Schippers J.H.M., \& Mueller Roeber B. Translatome and metabolome effects triggered by gibberellins during rosette growth in Arabidopsis. Journal of Experimental Botany, 2012. № 63(7). P. 2784.

${ }^{5}$ Wang Y., Gu W., Xie T., Li, L., Sun Y., Zhang H., Li, J., Wei S. Mixed compound of DCPTA and CCC increases maize yield by improving plant morphology and up-regulating photosynthetic capacity and antioxidants. Plos One, 2016. № 11(2). P. 25. DOI:10.1371/journal.pone.0149404.

${ }^{6}$ Poprotska I.V., Kuryata V.G. Features of gas exchange and use of reserve substances in pumpkin seedlings in conditions of skoto- and photomorphogenesis under the influence of gibberellin and chlormequatchloride. Regulatory Mechanisms in Biosystems. 2017. № 8(1). P. 73.
} 
антагоністи - ретарданти, які блокують синтез або утворення гормонрецепторного комплексу, внаслідок чого зменшується інтенсивність лінійного росту рослин ${ }^{7}$. У літературі міститься інформація про застосування гібереліну та антигіберелінових препаратів із метою оптимізації продукційного процесу шляхом анатомо-морфологічних та фізіолого-біохімічних змін у зернокруп'яних ${ }^{8,9,10}$, зернобобових ${ }^{11,12,13}$, олійних $^{14,15}$, овочевих ${ }^{16,17,18}$, лікарських і декоративних культур ${ }^{19,20,21}$.

Саліцилова кислота є природним рослинним гормоном і бере участь у реакціях рослин на різні біотичні та абіотичні фактори ${ }^{22}$. Вона відіграє

7 Рогач В.В., Рогач Т.I. Вплив синтетичних стимуляторів росту на морфофізіологічні характеристики та біологічну продуктивність культури картоплі. Вісник Дніпропетровського університету. Серія: Біологія, екологія. 2015. № 23(2). Р. 223.

${ }^{8}$ Mohammad N.K., Mohammad F. Effect of $\mathrm{GA}_{3}, \mathrm{~N}$ and $\mathrm{P}$ ameliorate growth, seed and fibre yield by enhancing photosynthetic capacity and carbonic anhydrase activity of linseed. Integrative Agriculture. 2013. № $12(7)$. P. 1187.

${ }^{9}$ Muhammad I., Muhammad A. Gibberellic acid mediated induction of salt tolerance in wheat plants: Growth, ionic partitioning, photosynthesis, yield and hormonal homeostasis. Environmental and Experimental Botany. 2013. № 86. P. 85.

${ }^{10}$ Yang L., Yang D., Yan X., Cui L., Wang Z., \& Yuan H. The role of gibberellins in improving the resistance of tebuconazole-coated maize seeds to chilling stress by microencapsulation. Scientific Reports. 2016. № 60. P. 10.

${ }^{11}$ Saeidi-Sar S., Abbaspour H., Afshari H., \& Yaghoobi S. R. Effects of ascorbic acid and gibberellin A3 on alleviation of salt stress in common bean (Phaseolus vulgaris L.) seedlings. Acta Physiologiae Plantarum. 2013. № 35(3). P. 674.

${ }^{12}$ Yan, W., Yanhong, Y., Wenyu, Y., Taiwen, Y., Weiguo, L., \& Wang, X. Responses of root growth and nitrogen transfer metabolism to uniconazole, a growth retardant, during the seedling stage of soybean under relay strip. Communications in Soil Science and Plant Analysis Intercropping System. 2013. № 44(22). P. 3274.

${ }^{13}$ Yan, Y., Wan, Y., Liu, W., Wang, X., Yong, T., \& Yang, W. Influence of seed treatment with uniconazole powder on soybean growth, photosynthesis, dry matter accumulation after flowering and yield in relay strip intercropping system. Plant Production Science. 2015. № 18(3). P. 299.

${ }^{14}$ Kumar S., Ghatty S., Satyanarayana J., \& Guha A. Paclobutrazol treatment as a potential strategy for higher seed and oil yield in fieldgrown Camelina sativa L. Crantz. BSK Research Notes. 2012. № 5. P. 9.

15 Matysiak K., Kaczmarek S. Effect of chlorocholine chloride and triazoles - tebuconazole and flusilazole on winter oilseed rape (Brassica napus var. oleifera L.) in response to the application term and sowing density. Journal of Plant Protection Research. 2013. № 53(1). P. 74.

${ }^{16}$ Khan A. L, Hamayun M., Kang S. M. Endophytic fungal association via gibberellins and indole acetic acid can improve plant growth under abiotic stress: an example of Paecilomyces formosus LHL10. BMC Microbiol. 2012. № 12:3. doi:10.1186/1471-2180-12-3

${ }^{17}$ Tae-Yun K., \& Jung-Hee H. Effects of hexaconazole on growth and antioxidant potential of cucumber seedlings under UV-B radiation. Journal of Environmental Science International. 2012. № 21(12). P. 1444.

${ }^{18}$ Pavlista A.D. Influence of foliar-applied growth retardants on russet burbank potato tuber production. American Journal of Potato Research. 2013. № 90, P. 395-400.

${ }^{19}$ Zhang W., Xu F., Hua C., \& Cheng S. Effect of chlorocholine chloride on chlorophyll, photosynthesis, soluble sugar and flavonoids of Ginkgo biloba. Notulae Botanicae Horti Agrobotanici Cluj-Napoca. 2013. № 41(1). P. 101.

${ }^{20}$ Sardoei A.S., Yazdi M.R., Shshdadneghad M. Effect of cycocel on growth retardant cycocel on reducing sugar, malondialdehyde and other aldehydes of Cannabis sativa L. International Journal of Biosciences. 2014. № 4(6). P. 132.

${ }^{21}$ Sugiura D., Sawakami K., Kojim M., Sakakibara H., Terashima I., Tateno M. Roles of gibberellins and cytokinins in regulation of morphological and physiological traits in Polygonum cuspidatum responding to light and nitrogen availabilities. Functional Plant Biology. 2015. № 42(4). P. 402

${ }^{22}$ Shama M.A., Moussa S.A.M. and Abo El Fade N.I. Salicylic acid efficacy on resistance of garlic plants (Allium sativum, L.) to water salinity stress on growth, yield and its quality. Alex.Sci.Exc.J. 2016. № 37(2). P. 170. 
життєво важливу роль у рості рослин, транспорті поглинання іонів та фотосинтезі $^{23}$, а також різноманітну регулюючу роль у рослинному обміні.

Відомо, що саліцилова кислота відіграє ключову роль у регулюванні багатьох фізіологічних процесах у рослинах. Її зовнішнє застосування сприяло підвищенню продуктивності рослин в умовах біотичного та абіотичного стресу ${ }^{24}$. Доведено, що обприскування розчином саліцилової кислоти збільшує вегетативний ріст, урожайність та якість цибулин часнику ${ }^{25,26,27}$, артишоку ${ }^{28}$, біохімічний склад часнику ${ }^{29,30}$, цибулі ${ }^{31,32}$, лежкість часнику ${ }^{33}$.

Застосування саліцилової кислоти сприяло росту та розвитку рослин. У зв'язку з цим ${ }^{34}$ виявлено, що саліцилова кислота відіграє важливу роль у формуванні цибулин. Khadr $(2015)^{35}$, уточнив, що обприскування рослин часнику саліциловою кислотою сприяло збільшенню висоти рослин, площі листя, загальної сирої та сухої маси. Крім того, досягнуто суттєвого збільшення вмісту суми хлорофілів $(a+b)$ та врожаю.

Гіберелінова кислота $\left(\Gamma_{3}\right)$ відіграє важливу роль у формуванні цибулин часнику ${ }^{36,} 37$. Листкове застосування гіберелінової кислоти

\footnotetext{
${ }^{23}$ Kazemi M. Foliar Application of Salicylic Acid and Calcium on Yield, Yield Component and Chemical properties of Strawberry. Bull. Env. Phar. Life Sci. 2013. № 2 (11). P. 20.

${ }^{24}$ Senaratna T., Touchell D., Bunn E., and Dixon K. Acetyl salicylic acid (Aspirin) and salicylic acid induce multiple stress tolerance in bean and tomato plants. Plant Growth Regulation. 2000. № 30. P. 159.

${ }^{25}$ Bardisi A. (a). Influence of vitamin $\mathrm{C}$ and Salicylic acid foliar application on garlic plants under sandy soil condition. Growth and plant chemical composition. Zagazig Journal of Agricultural Research. 2004. № 31(4A). P. 1346.

${ }^{26}$ Bardisi A. (b). Influence of vitamin C and Salicylic acid foliar application on garlic plants under sandy soil condition. Yield and its Storability. Zagazig Journal of Agricultural Research. 2004. № 31(4A). P. 1358.

27 Amin A.A., Rashad S.M. and El-Abagy H.M.H. Physiological effect of indol-3-butyric acid and salicylic acid on growth, yield and chemical constituents of onion plants. Journal of Applied Sciences Research. 2007. № 3(11). P. 1559.

${ }^{28}$ El-Zohiri S.S.M. Role of the salicylic and ascorbic acid on the control of growth, flowering and yield of globe artichoke. Annals of Agricultural Science Moshtohor Journal. 2009. № 47(3). P. 399.

${ }^{29}$ Bideshki A., Arvin M. J. and. Darini M. Interactive effects of Indole-3-butyric acid (IBA) and salicylic acid (SA) on growth parameters, bulb yield and allicin contents of garlic (Allium sativum) under drought stress in field. International Journal of Agronomy and Plant Production. 2013. № 4(2). P. 276.

${ }^{30} \mathrm{Khadr}$ A.A.I. Effect of salicylic acid and calcium on growth, yield and quality of garlic (Allium sativum L.) plants. M.Sc. thesis, Fac. Damanhour univ., Egypt, 2015. P. 96.

${ }^{31}$ Pradhan M., Tripathy P., Mandal P., Sahoo B. B., Pradhan R., Mishra S. P. and Mishra H. N. Effect of Salicylic Acid on Growth and Bulb Yield of Onion (Allium Cepa L.). International Journal of Bio-resource and Stress Management. 2016. № 7(4). P. 963.

${ }^{32}$ Prajapati S., Jain P.K. and Tiwari A. Effects of Salicylic acid (SA) and Azospirillum on growth and bulb yield of Onion (Allium cepa L.) cv. Agrifound Light Red. International Journal of Agriculture, Environment and Biotechnology. 2016. № 9(3). P. 400.

${ }^{33}$ Meena B., Aravindakshan K., Maurya I. B., Yadav I. and Singh D. Effect of Foliar Application of Salicylic Acid and Ethrel on Growth, Yield and Quality of Garlic (Allium Sativum L.) var. G282. Chemical Science Review and Letters. 2017. № 6(21). P. 603.

${ }^{34}$ Li C.X.; Yang J., Wang S.C., Xia K., Li S. and Zhou X. The role of salicylic acid in the swelling of garlic (Allium statium L.) bulb. Acta. Hort. Sin. 2000. № 27. P. 222.

35 Khadr A.A.I. Effect of salicylic acid and calcium on growth, yield and quality of garlic (Allium sativum L.) plants. M.Sc. thesis, Fac. Damanhour univ., Egypt, 2015. 101 pp.

${ }^{36}$ Rahim M.A. Control of growth and bulbing of garlic (Allium sativum L.) Ph.D. Thesis, University of London. 1988. P. 109.
} 
сприяє збільшенню в цибулині кількості зубків. Гіберелінова кислота покращує ріст i розвиток хлоропластів, підвищує ефективність фотосинтезу, що, в свою чергу, збільшує врожайність ${ }^{38}$. На основі експерименту Kumar S. ${ }^{39}$, зроблено висновок, що гіберелінова кислота мала значний вплив на ріст, якість та врожайність помідорів, застосування ГК 3 сприяло збільшенню висоти рослин, кількості листя, кількості плодів і їх маси, аскорбінової кислоти та сухих розчинних речовин. Встановлено, що гіберелінова кислота збільшує біомасу листя та активізує фотосинтетичні процеси у Polygonum cuspidatum.

Гіберелова кислота підвищує стійкість проростків бобів ${ }^{40}$ до засолення, підвищує їх продуктивність.

Аскорбінова кислота чинить стимулюючу дію на рослини, наприклад, iii застосування сприяло значному збільшенню висоти рослин та загального врожаю томатів ${ }^{41}$, аналогічні результати були отримані й іншими вченими ${ }^{42,43}$.

Аскорбінова кислота (АК) - це антиоксидант і ключовий субстрат для детоксикації активних утворень кисню ${ }^{44}$. Фізіологічно активна форма АК - це аскорбат ${ }^{45}$.

Обприскування розчином аскорбінової кислоти збільшувало висоту рослин, кількість листя, суху масу рослини та загальний урожай часнику ${ }^{46}$ та картоплі ${ }^{47}$.

\footnotetext{
${ }^{37}$ Rahim M.A. and Forhad R. Effect of storage temperature on the initiation and development of garlic cloves (Allium sativum L.). Horticultural Science. 1988. № 37. P. 35.

${ }^{38}$ Yuan L., Xu D. Q. Stimulation effect of gibberellic acid short-term treatment on the photosynthesis related to the increase in Rubisco content in broad bean and soybean. Photosynthesis Research. 2001. № 68. P. 46. DOI: 10.1023/A:1011894912421.

${ }^{39}$ Kumar S., Ghatty S., Satyanarayana J., \& Guha A. Paclobutrazol treatment as a potential strategy for higher seed and oil yield in fieldgrown Camelina sativa L. Crantz. BSK Research Notes. 2012. № 5. P. 12.

${ }^{40}$ Saeidi-Sar S., Abbaspour H., Afshari H., \& Yaghoobi S.R. Effects of ascorbic acid and gibberellin A3 on alleviation of salt stress in common bean (Phaseolus vulgaris L.) seedlings. Acta Physiologiae Plantarum. 2013. № 35(3). P. 666.

${ }^{41}$ Abdel-Halim S.M. Effect of some vitamins as growth regulators on growth, yield and endogenous hormones of tomato plants during winter. Egypt J Appl Sci. 1995. № 10 (12). P. 332.

${ }^{42}$ Helal F.A, Farag S.T, El-Sayed S.A. Studies on growth, yield and its components and chemical composition under effect of vitamin $\mathrm{C}$, vitamin $\mathrm{B}_{1}$, boric acid and sulphur on pea (Pisum sativum $\mathrm{L}$.) plants. J AgricSci, Mansoura Univ. 2005. № 30 (6). P. 3352.

${ }^{43}$ El-Banna E.N., Ashour S.A., Abd-El-Salam H.Z. Effect of foliar application with organic compounds on growth, yield and tubers quality of potato (Solanum tuberosum L.). J Agric Sci Mansoura Univ. 2006. №31 (2). P. 1171.

${ }^{44}$ Foyer, C.H., and Noctor, G. Ascorbate and glutathione: the heart of the redox hub. Plant Physiol. 2011. № 155. P. 16. doi: 10.1104/pp.110.167569

${ }^{45}$ Qian H.F., Pen X. F., Han X., Ren J., Zhan K.Y., and Zhu M. The stress factor, exogenous ascorbic acid, affects plant growth and the antioxidant system in Arabidopsis thaliana. Russ. J. Plant Physiol. 2014. № 61. P. 472. doi: 10.1134/S1021443714040141

${ }^{46}$ El-Morsy A.H.A., Ezzat A.S. and Saif El-Deen U.M. Effect of some phosphorus and potassium rates and foliar spray with antioxidants on growth, yield and yield quality of garlic (Allium sativum L.). Annals of Agricultural Science Moshtohor Journal. 2010. № 48 (3). P. 34.

${ }^{47}$ Gouda A.E.A.I., Gahwash M.N.M.A and Abdel- Kader A.E. Response of potato growth and yield to some stimulating compounds. J. Plant Production, Mansoura Univ., 2015. Vol. 6 (8). P. 1300.
} 
Часник - другий за поширеністю вид родини Цибулевих після цибулі. Він давно визнаний у всьому світі цінною приправою до їжі та популярним засобом від різних недуг та фізіологічних розладів. Часник також вважається однією з найважливіших лікарських рослин, що мають широкі харчові властивості та масово використовується у медицині, овоче- і м'ясоконсервній промисловості ${ }^{48}$.

Отже, численні літературні дані свідчать, що екзогенно застосовані гібереліни доволі часто призводять до одного і того самого результату оптимізації продукційного процесу сільськогосподарських культур i підвищення їх урожайності. 3 огляду на все вищесказане випливає, що ці амінокислоти вивчалися окремо або в певних комбінаціях у різних природних умовах, але їх вплив на фізіологічний стан рослин, продуктивність і зберігання часнику не вивчали і не порівнювали між собою. Тому порівняння впливу саліцилової, гіберелінової та аскорбінової кислот на ріст та врожайність рослин, оксидативний стан, загальний вміст вітамінів групи В та вміст аскорбінової кислоти в цибулинах стало метою дослідження.

\section{1. Матеріали та методи досліджень}

Дослідження впливу органічних кислот проводили впродовж 2017-2019 pp. в умовах Правобережного Лісостепу України на дослідному полі кафедри овочівництва Уманського національного університету садівництва відповідно до загальноприйнятих методик ${ }^{49}$. Грунт дослідного поля - чорнозем опідзолений важкосуглинковий.

Інформаційною базою для аналізу метеорологічних умов в роки проведення дослідження (2017-2019 рр.), які були загалом сприятливими для вирощування часнику озимого, була метеостанція «Умань». Використовувалися такі показники: середня декадна температура i вологість повітря та сумарна кількість опадів. Перебіг агрометеорологічних чинників за роки досліджень створював відповідні умови для росту і розвитку рослин часнику озимого.

Погодні умови вегетаційних періодів 2017-2019 рр. за основними метеорологічними показниками були неоднаковими, тому ефективність досліджених заходів оцінено об'єктивно, а отримані дані були достовірними.

Висаджування зубків часнику виконували за схемою $45 \times 6$ см 5-10 жовтня.

\footnotetext{
${ }^{48}$ Petropoulos S.A., Fernandes A., Ntatsi G., Petrotos K., Barros L. and. Ferreira I. C.F.R. Nutritional Value, Chemical Characterization and Bulb Morphology of Greek Garlic Landraces. Molecules. 2018. № 23 (2). Р. 319; doi:10.3390/molecules23020319

49 Методика дослідної справи в овочівництві і баштанництві / за ред. Г.Л. Бондаренко, К.І. Яковенко, Харків : Основа, 2001. С. 11, 43, 81-88, 90.
} 


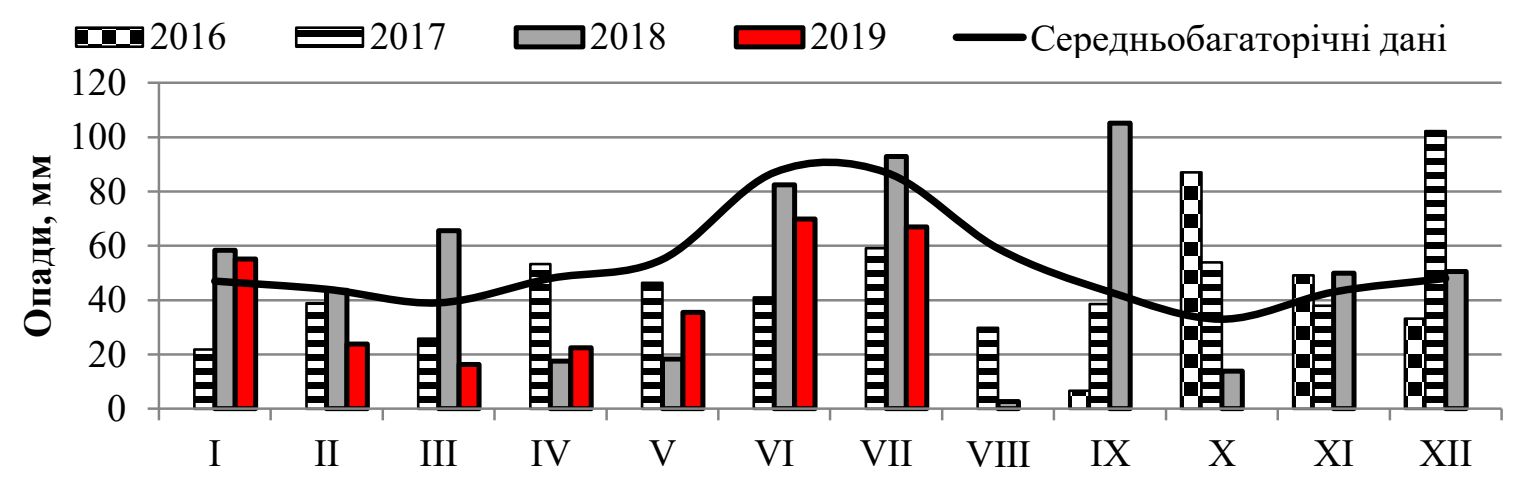

Рис. 1. Сума опадів, мм (2016-2019 рр.)

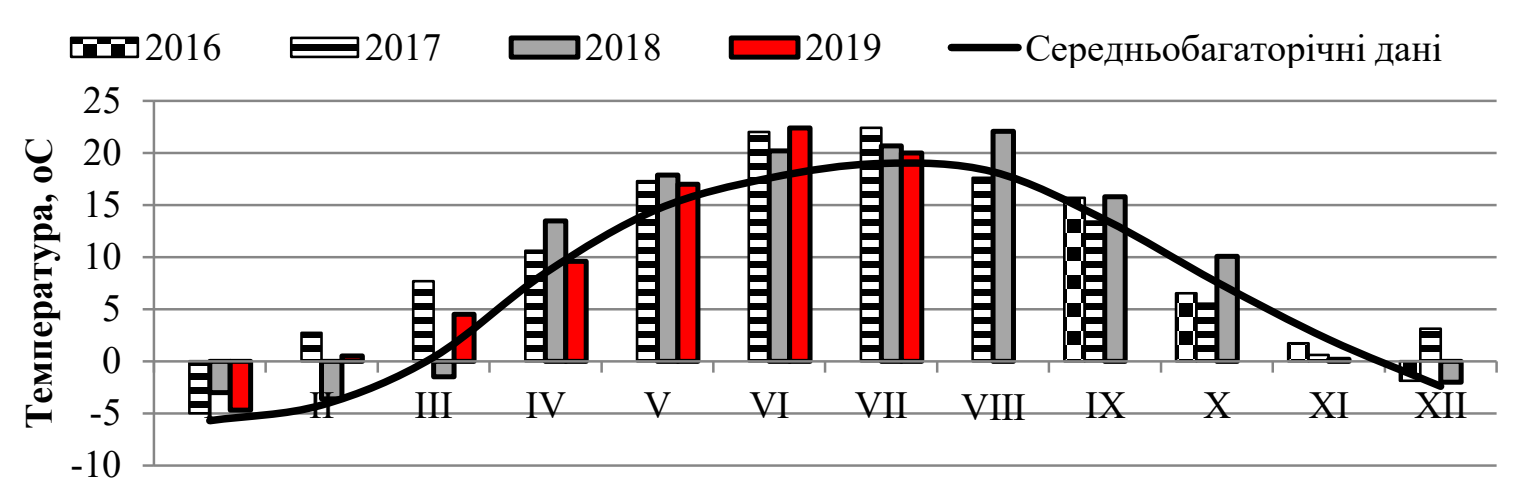

Рис. 2. Середня температура повітря, ${ }^{\circ} \mathrm{C}$ (2016-2019 рр.)

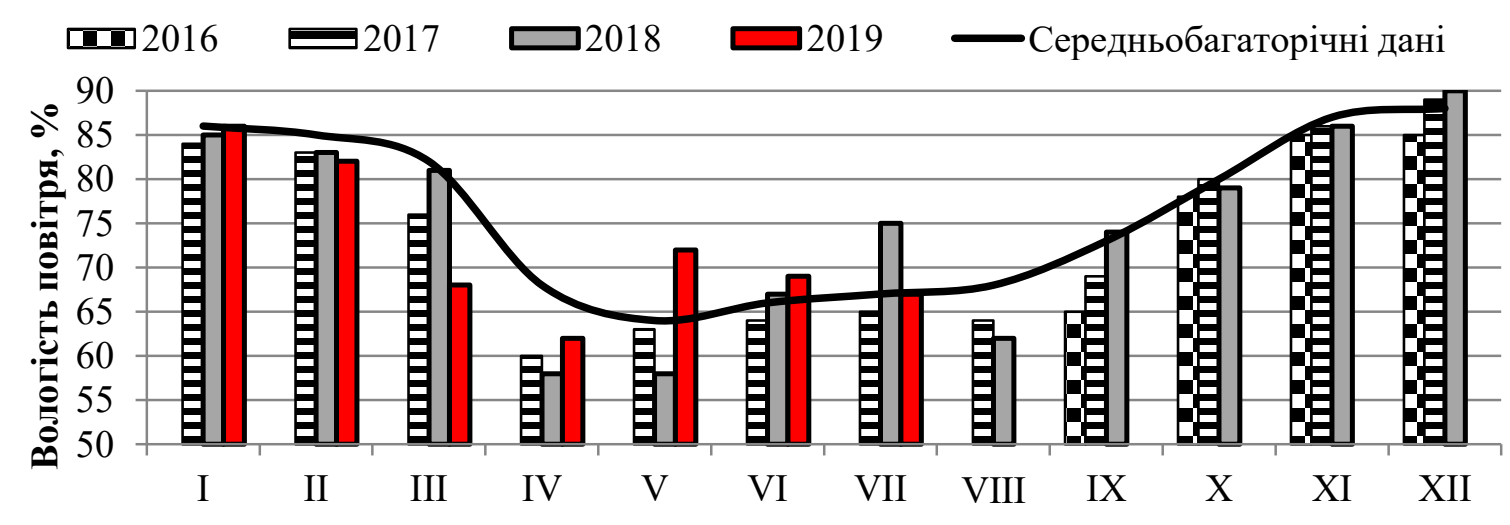

Рис. 3. Відносна вологість повітря, \% (2016-2019 рр.)

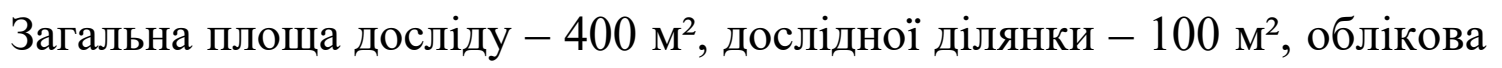
площа $-10 \mathrm{~m}^{2}$. Варіанти досліду розміщували системно, повторність чотириразова.

Дворазове обприскування рослин проводили на 40-у та 50-у добу після початку весняного відростання. В умовах Правобережного Лісостепу України на 40-у та 50-у добу початку весняного відростання 
спостерігається інтенсивне наростання вегетативної маси рослин часнику, саме в цей період мають місце останні весняні заморозки абіотичні стреси.

Однофакторний дослід складався 3 позакореневого застосування (обприскування) посівів часнику розчинами саліцилової кислоти (CA) $\mathrm{C}_{6} \mathrm{H}_{4}(\mathrm{OH}) \mathrm{COOH}(300 \mathrm{ppm})^{50}$, гіберелінової кислоти $\left(\Gamma_{3}\right)-\mathrm{C}_{19} \mathrm{H}_{22} \mathrm{O}_{6}$ $(150 \mathrm{ppm})^{51}$ та аскорбінової кислоти $(\mathrm{AK})-\mathrm{C}_{6} \mathrm{H}_{8} \mathrm{O}_{6}(200 \mathrm{ppm})^{52}$, а також контролю - обприскування водою.

У дослідженні визначали площу листка та загальну площу листя на рослині на 60-й день початку весняного відростання, висоту рослини та кількість листя (шт./росл.). Площу листкової пластинки визначали лінійним методом, використовуючи параметри довжини та ширини листка за формулою:

$$
\mathrm{Sn}=0.67 \times \mathrm{ab}
$$

де $\mathrm{Sn}$ - площа листка, см², a - ширина листка, cм, b - довжина листка, см, 0,67 - коефіцієнт конфігурації.

Досліджували вплив обприскування розчинами органічних кислот на активність антиоксидантних ферментів у листках рослин, вміст пігментів у листках, комплекс вітамінів групи В та вміст аскорбінової кислоти в зубках часнику озимого.

Для дослідження лежкості цибулин часнику відбирали 5 кг типових цибулин, непошкоджених та без зовнішніх ознак ураження шкідниками і хворобами ${ }^{53,54}$.

Рослинний матеріал: Часник озимий (Allium sativum L.), сорт Любаша.

Вміст пігментів визначали спектрофотометричним методом ${ }^{55}$.

Визначення активності антиоксидантних ферментів проводили 3 використанням спектрофотометра СФ-2000. Аналізували активність супероксиддисмутази (СОД), гваяколпероксидази (ГвПО), каталази (KАТ), глутатіон редуктази (ГР) і глутатіон S-трансерази (ГST).

\footnotetext{
${ }^{50}$ Shama M.A., Moussa S.A.M. and Abo El Fade N.I. Salicylic acid efficacy on resistance of garlic plants (Allium sativum, L.) to water salinity stress on growth, yield and its quality. Alex.Sci.Exc.J. 2016. № 37(2). P. 167.

${ }^{51}$ Abd-Elkader, D.Y. Effect of Foliar Spraying with Micronutrients and Salicylic Acid on Growth, Yield and Quality of Garlic Plants. Alexandria Journal of Agricultural Sciences. 2016. № 61 (6). P. 651.

${ }^{52} \mathrm{Naz}$ H., Akram N.A., and Ashraf M. Impact of ascorbic acid on growth and some physiological attributes of cucumber (Cucumis Sativus) plants under water-deficit conditions. Pakistan Journal of Botany. 2016. № 48(3). Р. 879.

53 Волкодав В.В. Методика державного сортовипробування сільськогосподарських культур (картопля, овочі та баштанні культури). Київ, 2001. 101 с.

${ }_{54}$ Методика проведення експертизи сортів рослин картоплі та груп овочевих, баштанних, пряносмакових на придатність до поширення в Україні. Київ, 2016.

${ }^{55}$ Методы биохимического исследования растений / за ред. А.И. Ермакова, изд. 3, дополненное и исправленное. Ленинград : Агропромиздат, 1972. С. 188.
} 
Рослинний матеріал $(0,3$ г) розтирали в 3 мл 0,1 MК, Na-фосфатного буфера (рН 7,8). Гомогенат центрифугували протягом 20 хв при $14000 \mathrm{~g}$ і температурі $4{ }^{\circ} \mathrm{C}$; у супернатанті визначали активність ферментів.

Загальну активність СОД визначали за здатністю фермента інгібувати фотохімічні відновлення нітросинім тетразолієм до формазану відповідно до методики ${ }^{56,57}$. Реакційне середовище (2 мл) містило 0,1 МК, Na-фосфатний буфер (pH 7,8), 9,3 мM L-метіонін, 152,3 мкМ нітросиній тетразолій, 1,1 мкМ трилон Б, 2,4\% Тритон X-100 і 100 мкл ферментативного препарату. Реакцію запускали додаванням 50 мкл 111,3 мкМ розчину рибофлавіну i проводили на світлі (освітленість ФАР 180 мкмоль $/ \mathrm{M}^{2} \cdot \mathrm{c}$ ) протягом 30 хв. Темновим контролем служило повне реакційне середовище, інкубована в темноті, а світловим - повне реакційне середовище, інкубоване на світлі, без додавання ферментативного екстракту, замість нього використовували 100 мкл 0,1 МК, Na-фосфатного буферу (pH 7.8). Реакцію зупиняли, поміщаючи проби в темряву. Оптичну щільність визначали при 560 нм на спектрофотометрі. Активність СОД виражали в ум. од./мг білка.

Активність КАТ в супернатанті визначали за ферментативним розкладанням $\mathrm{H}_{2} \mathrm{O}_{2}$ при 240 нм $^{58,59}$. Реакційне середовище містило 2 мл 0,1 МК, Na-фосфатного буферу (pH 7,0), 50 мкл 19.4 мМ $\mathrm{H}_{2} \mathrm{O}_{2}$. До отриманої суміші додавали 60 мкл ферментативного препарату i фіксували динаміку зміни оптичної щільності на спектрофотометрі протягом 1 хв. Активність КАТ виражали в мкмоль $\mathrm{H}_{2} \mathrm{O}_{2} /($ мг білка/хв) на основі коефіцієнту молярної екстинкції $\varepsilon=39.6 \mathrm{M}^{-1} \mathrm{~cm}^{-1}$.

Активність ГвПО визначали, виходячи зі збільшення оптичної щільності при 470 нм у результаті окислення гваяколу $\left(\varepsilon=26,6 \mathrm{MM}^{-1} \mathrm{~cm}^{-1}\right)$ за наявності $\mathrm{H}_{2} \mathrm{O}_{2}{ }^{60,61}$. Реакційне середовище містило 3 мл $0,1 \mathrm{M} \mathrm{K}$, Naфосфатного буферу (pH 6,2), 30 мкл 9,5 мМ $\mathrm{H}_{2} \mathrm{O}_{2}, 30$ мкл 9 мМ гваяколу. До отриманої суміші додавали 50 мкл ферментативного препарату i визначали динаміку зміни оптичної щільності на спектрофотометрі

56 Beauchamp Ch., Fridovich I. Superoxide dismutase improved assays and an assay applicable to acrylamide gels. Anal. Biochem. 1971. Vol. 44 (1). P. 278.

${ }^{57}$ Dhindsa R.S., Plumb-Dhindsa P., Thorpe T.A. Leaf senescence: correlated with increased levels of membrane permeability and lipid peroxidation, and decreased levels of superoxide dismutase and catalase. J. Exp. Bot. 1981. № 32: 94.

${ }^{58}$ Aebi H. Catalase in vitro. Methods in Enzymol. 1984. Vol. 105. P. 122.

${ }^{59}$ Upadhyaya A., Sankhla D., Davis T. D., Sankhla N., Smith B. N. Effect of paclobutrazol on the activities of some enzymes of activated oxygen metabolism and lipid peroxidation in senescing soybean leaves. J. Plant Physiol. 1985. № 121. P. 455.

${ }^{60}$ Upadhyaya A., Sankhla D., Davis T.D., Sankhla N., Smith B.N. Effect of paclobutrazol on the activities of some enzymes of activated oxygen metabolism and lipid peroxidation in senescing soybean leaves. J. Plant Physiol. 1985. № 121. P. 455.

${ }^{61}$ Sun J., You X.R., Li L., Peng H.X., Su W.Q., Li C.B., He Q.G., Liao F. Effects of a phospholipase D inhibitor on postharvest enzymatic browning and oxidative stress of litchi fruit. Postharvest Biol. Technol. 2011. № 62. P. 288-290. 
протягом 1 хв. Активність ГвПО виражали в мкмоль тетрагваяколу (мг білка/хв).

Активність ГР визначали, виходячи зі збільшення оптичної щільності при 470 нм у результаті окислення 5,5'-дитиобіс (2-нітробензойна кислота) (DTNB) знижувався за допомогою глутатіону (GSH), що утворюється 3 дисульфіду глутатіону (GSSG) ${ }^{62}$. Загальну активність виражали як кількість зниженого дисульфіду глутатіону (GSSG), мкмоль/хв білка мг, $\varepsilon 420=13,6 \mathrm{MM}^{-1} \mathrm{~cm}^{-1}$.

Активність ГST визначали спектрофотометрично за допомогою штучного субстрату, 1-хлор-2,4-динітробензолу (CDNB) ${ }^{63}$. Одна умовна одиниця - кількість фермента, що утворює кон'югований продукт 1 мкмоль $/ 1$ хв, $\varepsilon 340=9,6 \mathrm{MM}^{-1} \mathrm{~cm}^{-1}$.

Визначення вмісту сухої речовини, (\%). Середню масу сухої речовини (г-1) цибулин після визначали шляхом висушування 10 випадково відібраних цибулин У термостаті з примусовою циркуляцією гарячого повітря при за $\mathrm{t}^{\mathrm{o}} 105^{\circ} \mathrm{C}$ згідно ДСТУ $7804: 2015^{64}$ до отримання постійної ваги. Відсоток сухої речовини цибулини обчислили, взявши відношення сухої маси до свіжої маси відбірних цибулин і помноживши його на 100.

\section{Визначення вмісту вітамінів.}

Комплекс вітамінів групи $\mathrm{B}$, вміст вуглеводів i вільних цукрів визначали за рекомендаціями 3 продовольства i харчування методом тонкошарової хроматографії (ТШХ) гідролізатів отриманих фракцій, а також високоефективної рідинної хроматомас-спектрометрії (HPLS) (Knauer, Smartline system 1000, Berlin, Germany) (Shimadzu, Model Prominence $20 \mathrm{~A})^{65}$.

Вміст аскорбінової кислоти визначали йодометричним методом Муррі згідно з ДСТУ 4958:2008

Режими зберігання часнику. Упродовж періоду зберігання показники температури повітря та відносної вологості за теплого режиму зберігання були порівняно стабільними, а за холодного - суворо контрольованими і зберігалися на одному рівні впродовж усього періоду (рис. 4 та 5).

\footnotetext{
${ }^{62}$ Smith I.K., Vierheller T.L., Thorne C.A. Assay of glutathione reductase in crude tissue homogenates using 5,5'-dithiobis(2-nitrobenzoic acid). Anal. Biochem. 1988. № 175. P. 410.

${ }^{63}$ Habig W.H., Pabst M.J., Jakoby W.B. Glutathione S-transferases. The first enzymatic step in mercapturic acid formation. J. Biol. Chem. 1974. № 246. P. 7131.

${ }^{64}$ ДСТУ 7804:2015. Продукти переробляння фруктів та овочів. Методи визначання сухих речовин або вологи. [Чинний від 2015-06-22]. Київ : Держспоживстандарт України, 2015. 19 с.

${ }^{65}$ Food and Nutrition Board. Institute of Medicine. Dietary Reference Intakes for Thiamin, Riboflavin, Niacin, Vitamin B6, Folate, Vitamin B12, Pantothenic Acid, Biotin and Choline. Washington, DC: National Academy Press. 2000. P. 348.

${ }^{66}$ ДСТУ 4958:2008. Фрукти, овочі та продукти їх перероблення. Метод визначення аскорбінової кислоти [Чинний від 2009-07-1]. Київ, 2009. 4 с.
} 


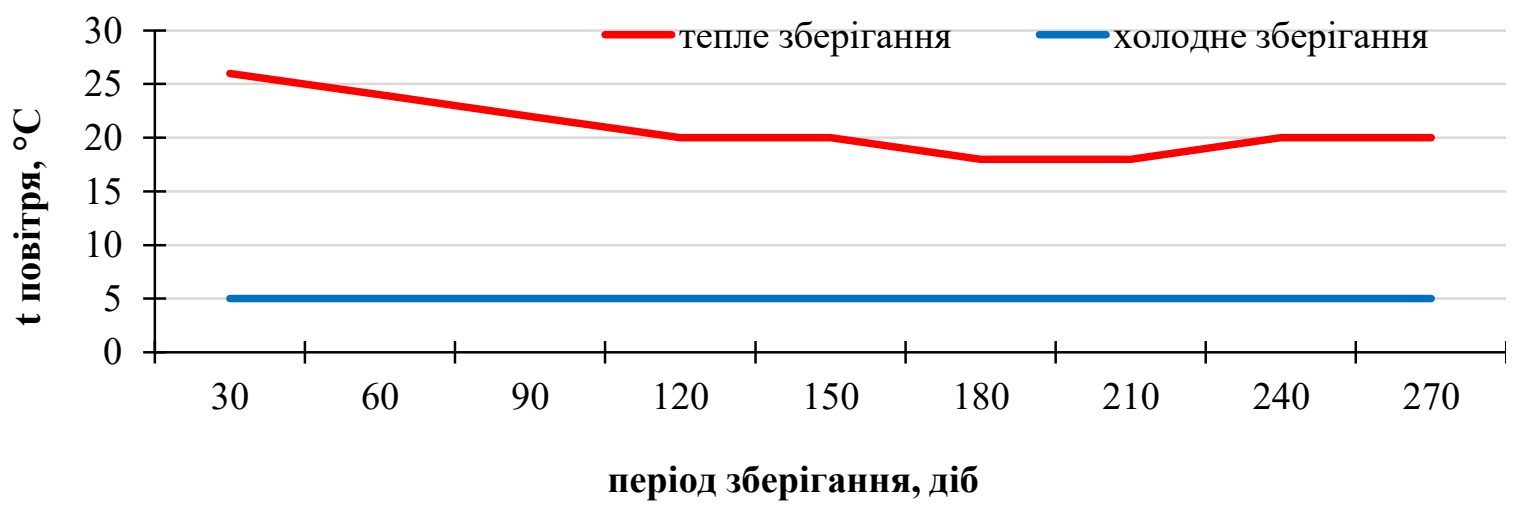

Рис. 4. Показники температури повітря $\left({ }^{\circ} \mathrm{C}\right)$ за умов теплого і холодного зберігання

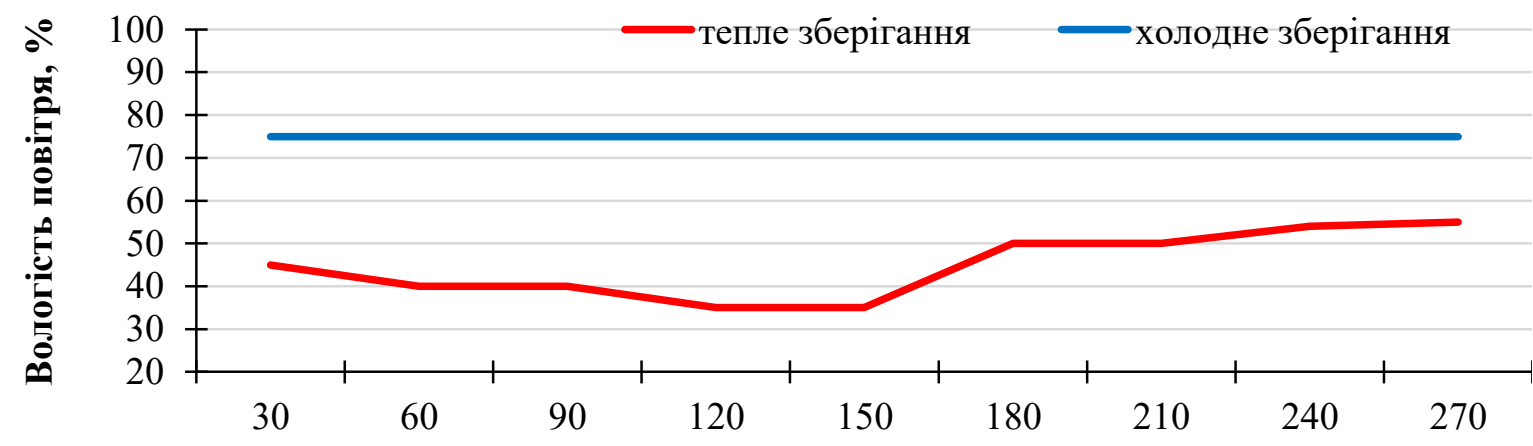

Період зберігання, діб

Рис. 5. Показники відносної вологості повітря (\%) за умов теплого і холодного зберігання

\section{2. Результати та обговорення}

Отримані результати досліджень показали, що максимальному збільшенню висоти рослин найкраще сприяла гіберелінова кислота, де цей показник був вищим проти контролю на 10,8\%, тоді як застосування саліцилової і аскорбінової кислот збільшувало висоту рослин на 7,8 та 3,9\% (табл. 1).

Основним показником росту та показником, від якого залежить продуктивність рослин часнику, $\epsilon$ листковий апарат, тому ми досконально його вивчали. Кількість листків на рослині за застосування гіберелінової та аскорбінової кислот збільшувалася на 0,46-0,55 шт./росл. $(5,3-6,3 \%)$, в той час саліцилова кислота несуттєво зменшувала цей показник на 0,15 шт./росл. $(1,7 \%)$ при цьому листкова площа зростала на $8,3,27,7$ та $4,8 \%$ за застосування саліцилової, гіберелінової та аскорбінової кислот. Листкова площа однієї рослин та листковий індекс мали дещо іншу динаміку, проте гіберелінова кислота показувала найкращі результати. 
Таблиця 1

Показники росту рослин, листкового і пігментного комплексу часнику озимого сорту Любаша за дії органічних кислот (2017-2019 рр.)

\begin{tabular}{|c|c|c|c|c|c|c|}
\hline Варіант & 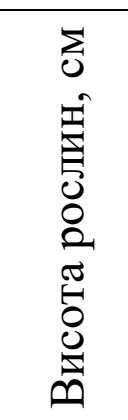 & 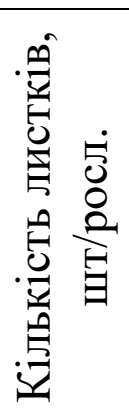 & 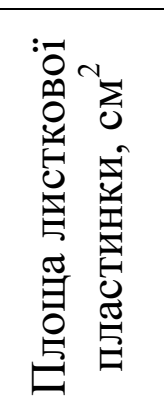 & 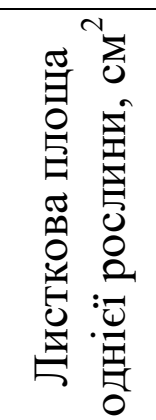 & 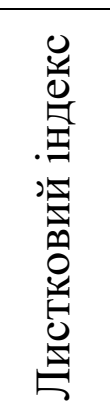 & 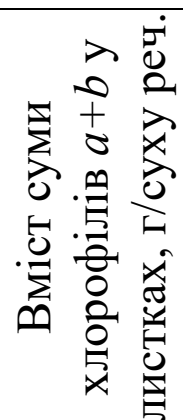 \\
\hline Контроль & 63,37 & 8,73 & 95,70 & 491,59 & 1,82 & 1,64 \\
\hline $\mathrm{CK}$ & 68,33 & 8,58 & 103,63 & 522,81 & 1,94 & 1,68 \\
\hline$\Gamma \mathrm{K}$ & 70,21 & 9,28 & 122,20 & 667,30 & 2,47 & 1,81 \\
\hline $\mathrm{AK}$ & 65,86 & 9,19 & 100,25 & 541,86 & 2,00 & 1,68 \\
\hline HIP $(0,01)$ & 3,45 & 0,40 & 6,06 & 31,6 & 0,14 & 0,135 \\
\hline
\end{tabular}

Рослини оброблені амінокислотами збільшували вміст суми хлорофілів $a+b$, але за застосування гіберелінової кислоти приріст був найбільш суттєвим до контролю - 0,17\% / суху речовину $(10,8 \%)$ (табл. 1$)$.

У рослинних клітинах спостерігається певний рівень ліпідів для окислення, який залишається постійним завдяки системам антиоксидантного захисту. Істотна роль у захисті клітин від окислювальної деструкції належить ферментній системі, зокрема, супероксиддисмутазі, яка каталізує реакцію супероксидних радикалів (О-). Швидкість взасмодії СОД і О залежить від ступеня гідратації клітин ${ }^{67}$. Результати дослідження, показані в таблиці 2, підтверджують дані, про які повідомлялося. У рослинах, оброблених саліциловою, гібереліновою та аскорбіновою кислотами зафіксовано збільшення активності СОД у листі на 9,1, 15,0 та 7,5\% порівняно з активністю ферментів у контрольному варіанті. Застосування амінокислот забезпечило активізацію комплексу антиоксидантних ферментів.

Активність СОД, КАТ, ГвПО, ГР, ГSТ у листках оброблених амінокислотами рослин часнику мали тенденцію до підвищення. Так, активність СОД була вищою від контролю 7,5-15,0\%, КАТ - 27,4-45,9\%, ГвПО - 7,0-83,0\%, ГР - 5,4-49,9\%, ГSТ - 14,8-41,3\% (табл. 2).

Отримані результати свідчать про те, що найвищу фізіологічну активність проявляе саме гіберелінова кислота, де активність антиоксидантного комплексу суттєво вища як проти контролю, так i проти інших дослідних варіантів.

\footnotetext{
${ }^{67}$ Asada K. Production and scavenging of reactive oxygen species in chloroplasts and their functions. Plant Physiol. 2006. № 141(2). P. 395. 
Таблиця 2

Активність антиоксидантних ферментів у листках часнику озимого сорту Любаша за дії органічних кислот (2017-2019 рр.)

\begin{tabular}{|c|c|c|c|c|c|}
\hline \multirow{2}{*}{} & \multicolumn{5}{|c|}{ Активність антиоксидантних ферментів (ум. од/мг білка) } \\
\cline { 2 - 6 } & ГвПО & СОД & КАТ & ГР & ГSТ \\
\hline Контроль & 85,63 & 9,77 & 7,78 & 10,07 & 27,32 \\
\hline СК & 110,90 & 10,66 & 10,82 & 11,18 & 31,44 \\
\hline ГК & 156,71 & 11,24 & 11,35 & 15,10 & 38,59 \\
\hline АК & 91,60 & 10,50 & 9,91 & 10,62 & 31,37 \\
\hline НІР $(0,01)$ & 8,715 & 1,100 & 0,721 & 0,998 & 0,721 \\
\hline
\end{tabular}

Результати дослідження вказали на значний вплив органічних кислот на врожайність та їі структуру (рис. 6, 7, 8), а саме, масу цибулини та вміст сухої речовини, вітамінів групи В та вітаміну С, всі ці структурні елементи мали кращі показники в усіх варіантах порівняно з контролем.

Маса цибулини збільшувалася на 4,73; 9,26 та 4,55 г $(\mathrm{HIP}(0.05)=4,05)$ за застосування саліцилової, гіберелінової та аскорбінової кислот відповідно (рис. 6). Зростання врожайності мало таку ж динаміку. За застосування саліцилової, гіберелінової та аскорбінової кислот врожайність часнику збільшувалася на 1,$18 ; 2,27$ та 1,14 т/га (HIP 0,05)= $=0,89)$ (рис. 7). Проте вміст сухої речовини (рис. 8) у цибулинах часнику за застосування амінокислот на найвищому рівні був за використання саліцилової кислоти $+4,0 \%$ до контролю та аскорбінової кислоти $+3,7 \%$ до контролю. Гіберелінова кислота зумовлювала мінімальний приріст сухої речовини (рис. 8).

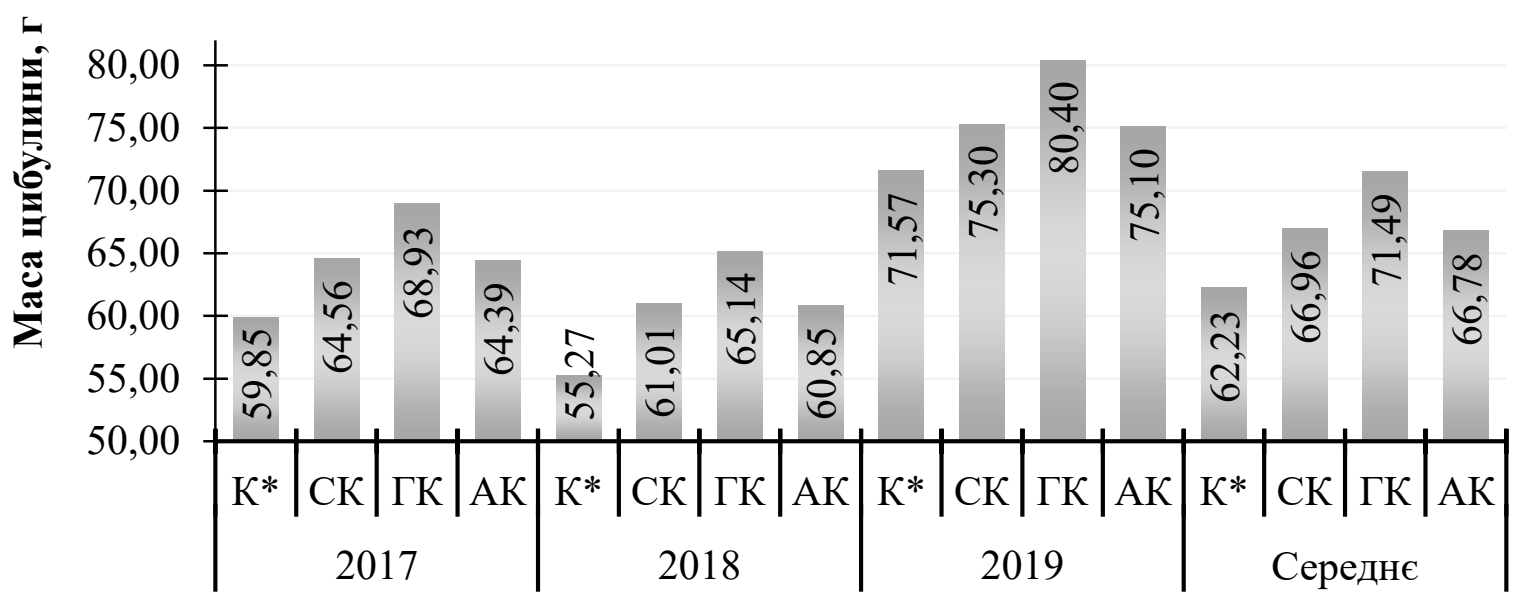

Рис. 6. Маса цибулини часнику озимого сорту Любаша за дії органічних кислот (HIP 05 : 2017 - 3,26; 2018 - 2,95; 2019 - 5,76) 


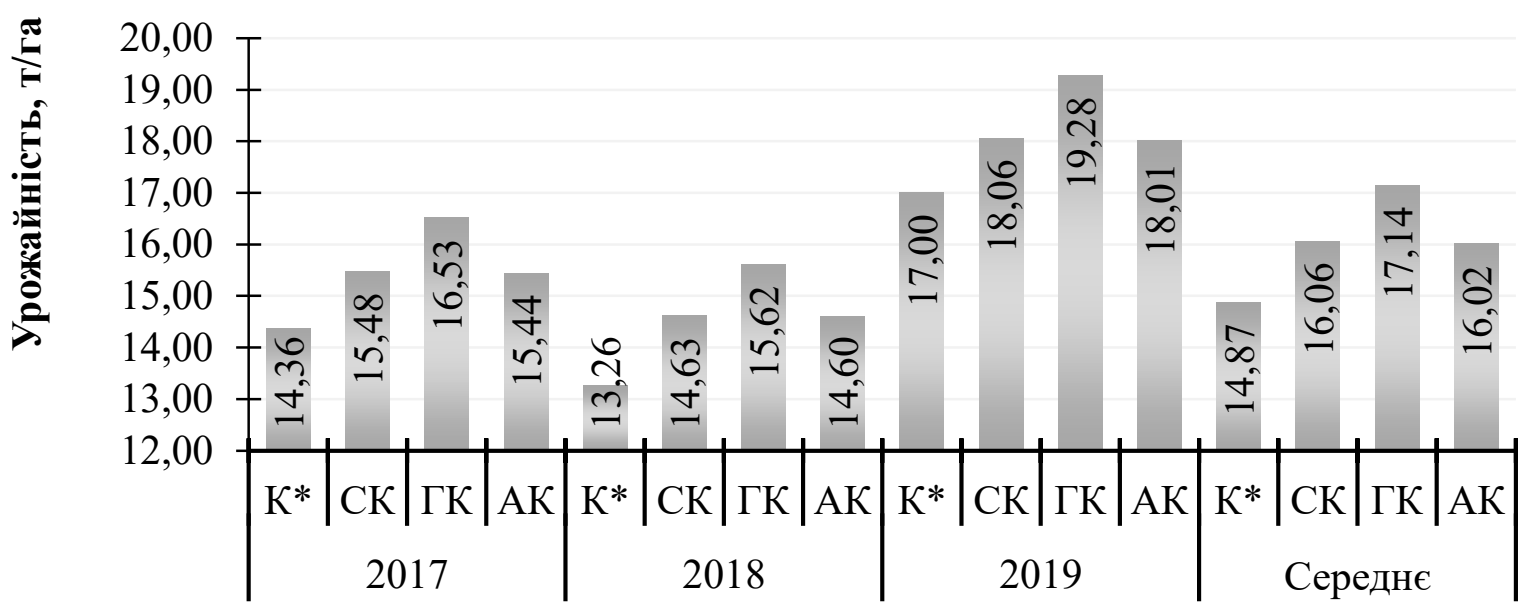

Рис. 7. Урожайність часнику озимого сорту Любаша за дії органічних кислот $\left(\right.$ HIP $_{05}: 2017$ - 0,73; 2018 - 0,86; 2019 - 0,89)

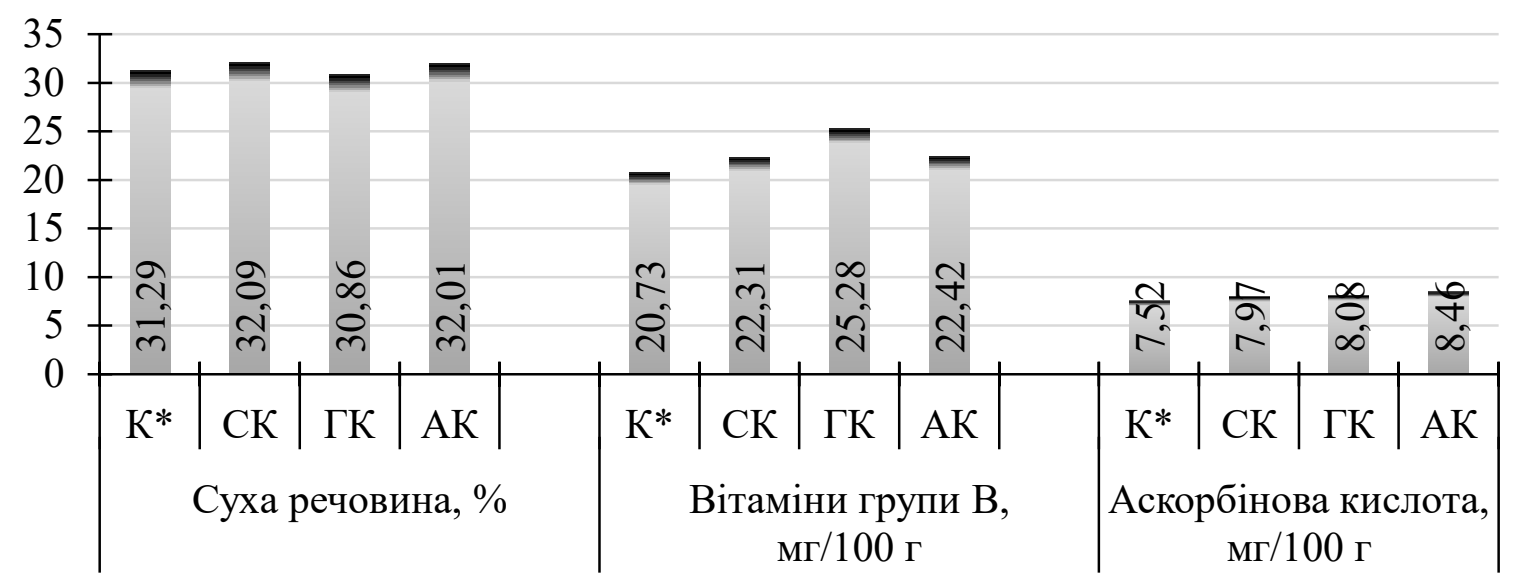

Рис. 8. Окремі показники біохімічного складу цибулин часнику озимого сорту Любаша за дії органічних кислот (HIP ${ }_{05}$ : суха речовина - 2,725; вітаміни групи В - 2,128; аскорбінова кислота - 0,558)

Дослідження вмісту вітамінів групи В (рис. 8) у зубках часнику показало, що найкращий ефект на їх накопичення мала гіберелінова кислота, де збільшення суми вітамінів групи В сягало 21,9\%, застосування саліцилової і аскорбінової кислот збільшувало їх суму до 7,6 та 8,2\%. Найсуттєвіше збільшення вмісту вітаміну С зазначено за обприскування рослин аскорбіновою кислотою - $+12,5 \%$ тоді, як за обприскування саліциловою і гібереліновою кислотами його вміст зростав на 6,0 та 7,5\%. 


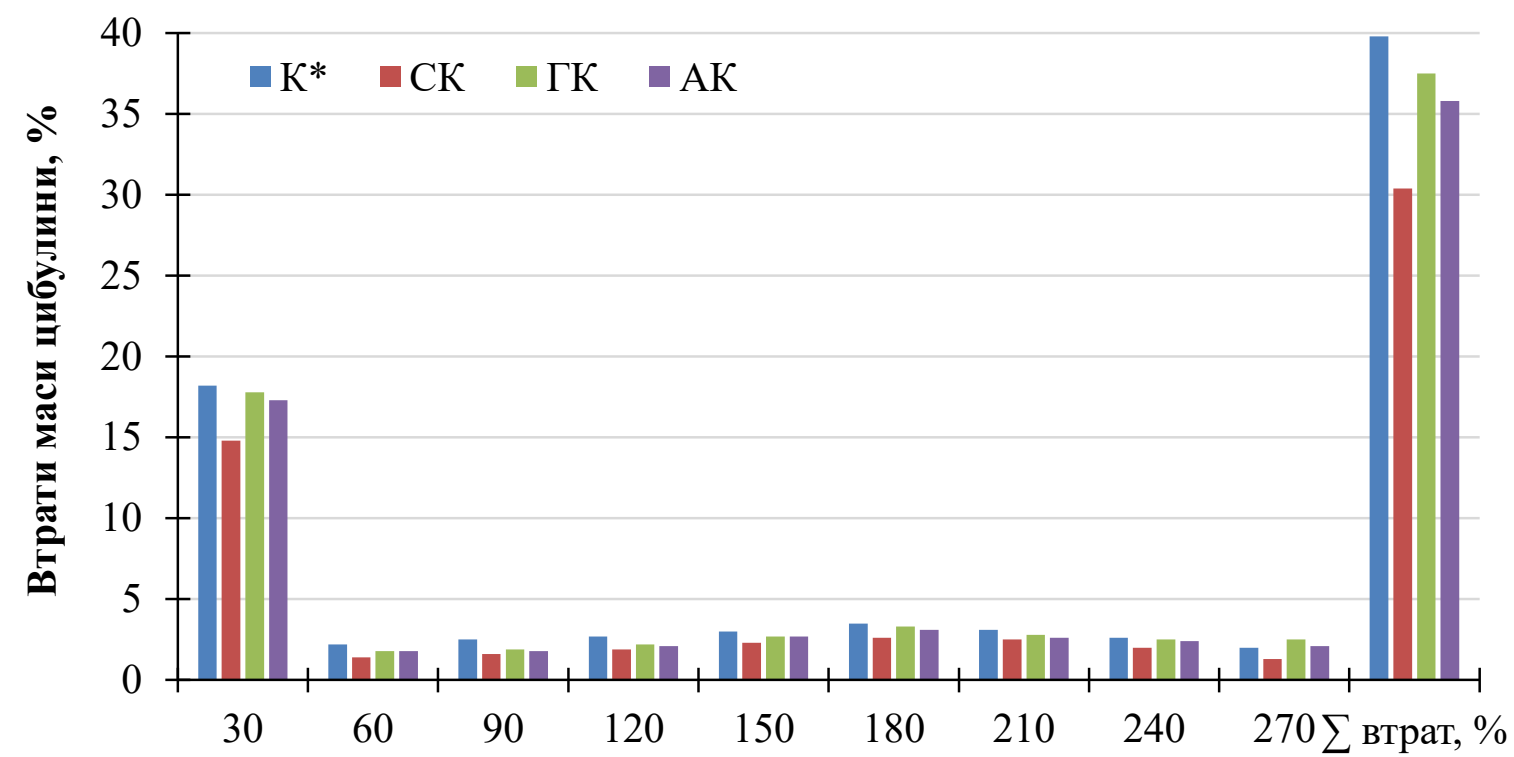

Рис. 9. Вплив органічних кислот на лежкість цибулин часнику озимого сорту Любаша за теплого способу зберігання (2017-2019 рр.)

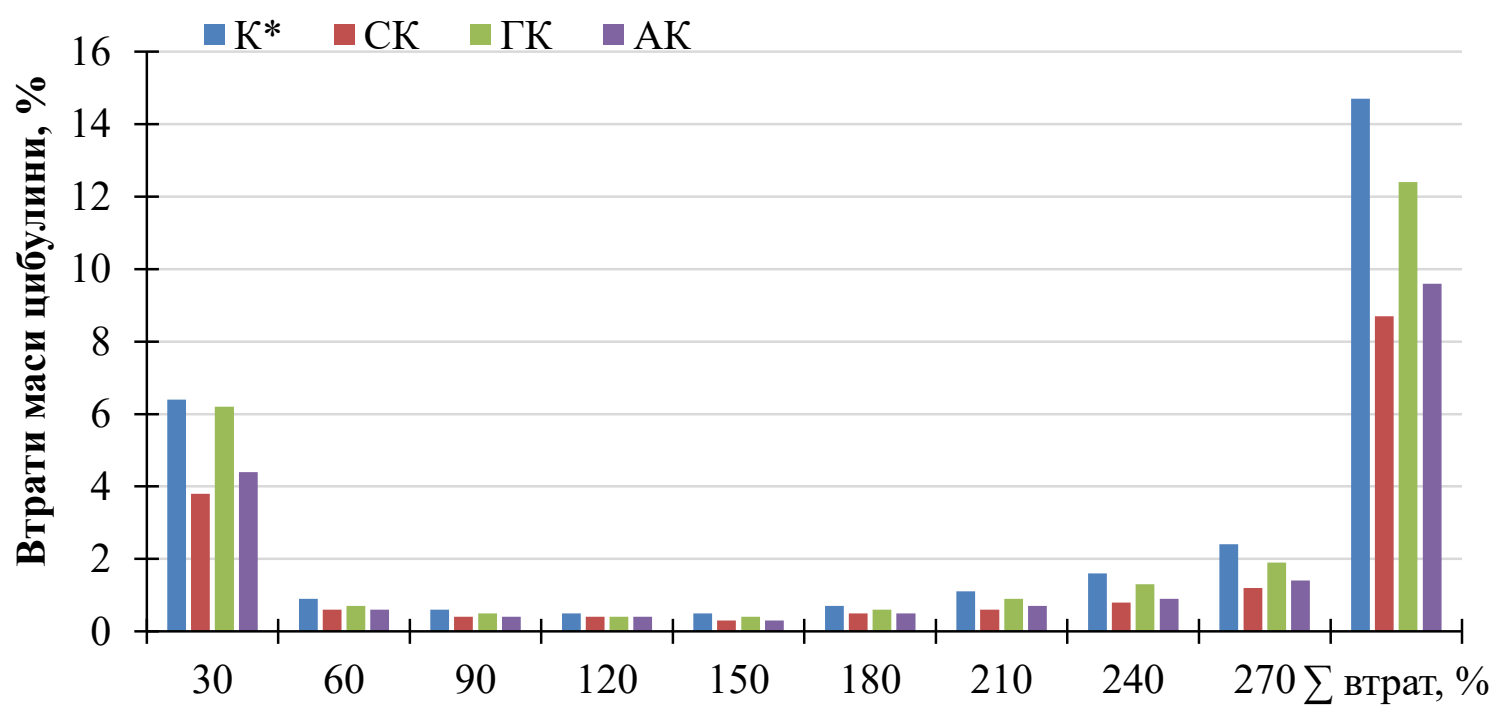

Рис. 10. Вплив органічних кислот на лежкість цибулин часнику озимого сорту Любаша за холодного способу зберігання (2017-2019 pp.)

Від тривалості періоду спокою (до проростання) зубків часнику втрачається їх товарність. У період зберігання товарність цибулин часнику із застосуванням ГК у середньому за роки досліджень до 140-150 діб за теплого зберігання та до 210-230 діб за холодного зберігання (рис. 9 і 10).

Використання СК та АК сприяло продовженню товарності цибулин часнику до 210 днів за теплого зберігання та до 240-260 діб за 
холодного. За теплого після 210 та за холодного зберігання 260 діб відбувалося масове проростання зубків. Цибулини контрольного варіанту та із застосуванням ГК проростали через 120 i 180 та 190-210 діб відповідно до варіанту та режиму зберігання. Результати дослідження свідчать про те, що використання ГА на посівах часнику недоцільно, якщо продукція буде закладатися на тривале зберігання. Подальше зберігання (до 270 діб) показує лише теоретичні дані про втрату маси цибулин.

У результаті статистичної обробки даних, виявлено середньої сили зв'язок між вмістом сухої речовини в цибулині перед закладанням на зберігання та втратами іiі маси упродовж періоду зберігання, де коефіцієнт апроксимації збільшується від 0,52 (за теплого зберігання) до 0,62 (за холодного зберігання) (рис. 11).

Результати цього дослідження виявили, що обприскування рослин розчинами органічних кислот збільшувало параметри росту. Це пов'язано 3 тим, що органічні кислоти посилюють процеси обміну речовин у тканинах рослин.

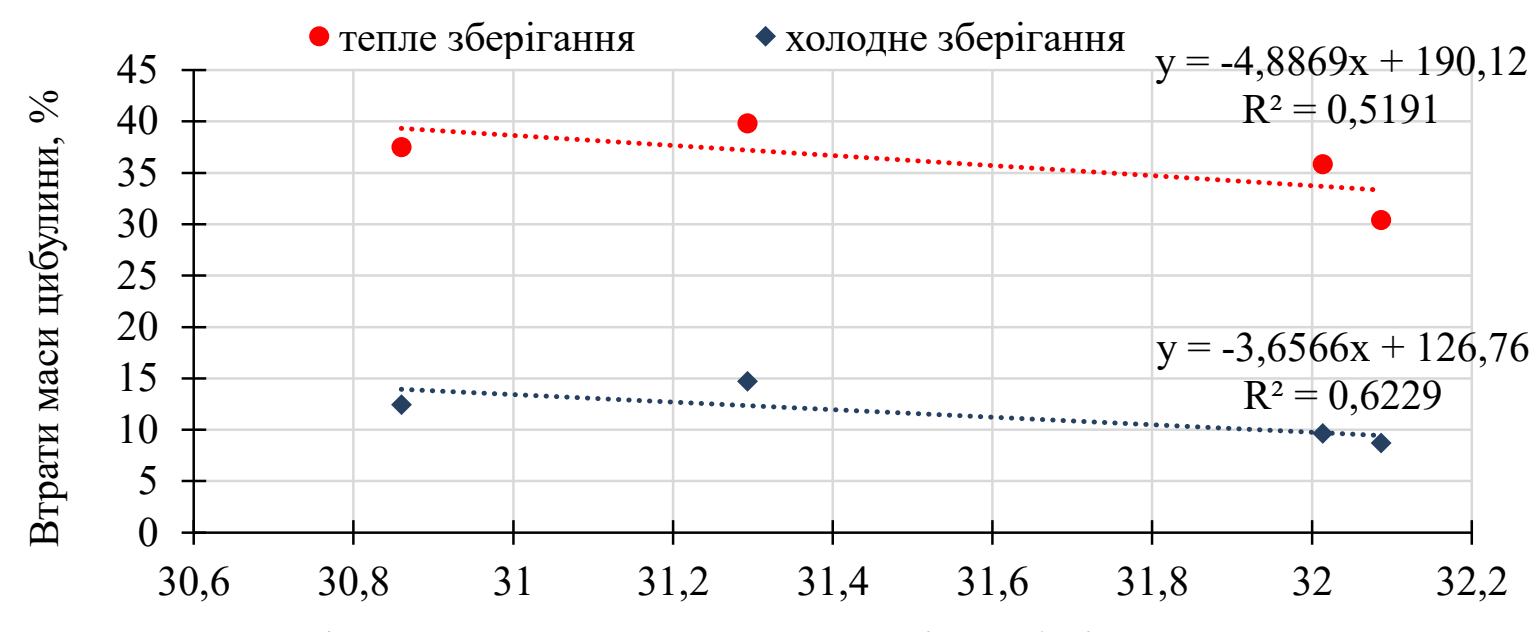

Вміст сухої речовини на початку періоду зберігання, \%

\section{Рис. 11. Статистична модель залежності вихідного вмісту сухої речовини 3 втратами маси цибулини під час зберігання}

У цьому відношенні застосування аскорбінової та гіберелінової кислот призвело до більш високого росту та врожаю баклажанів ${ }^{68}$. Наші результати подібні до отриманих даних інших вчених Paul et al. ${ }^{69,70,71}$.

${ }^{68}$ El-Tohamy W.A., El-Abagy H.M., El-Greadly H.M. Studies on the effect of putrescine, yeast and vitamin $\mathrm{C}$ on growth, yield and physiological responses of eggplant (Solanum melongena $\mathrm{L}$.) under sandy soil conditions. Aust J Basic Appl Sci. 2008. № 2 (2). P. 299.

${ }^{69}$ Abd El-Aal F.S., Shaheen A.M., Ahmed A.A., Mahmoud R. Effect of foliar application of urea and amino acids mixtures as antioxidants on the growth and yield and characteristics of squash. Res $J$ Agric Biol Sci. 2010. № 6(5). P. 587. 
Такі результати щодо стимулюючого впливу аскорбінової кислоти на інші рослини також були помічені ${ }^{72,73}$. S.M. Abdel-Halim ${ }^{74}$ виявив, що застосування аскорбінової кислоти на рослинах томатів значно збільшувало довжину стебла, кількість листків, квітів і плодів, ріст плодів їх масу та загальний урожай.

\section{ВИСНОВКИ}

Антиоксидантний вплив органічних кислот проявив тенденцію оптимізації цих параметрів.

Органічні кислоти підвищували адаптаційний потенціал рослин та оптимізували процеси росту і врожайності. Дослідження виявило, що застосування органічних кислот покращує продуктивність часнику загалом порівняно з контролем. Зазначено збільшення висоти рослини часнику, кількості листя, вміст сухої речовини. Найвищий урожай і маса цибулини були отримані внаслідок обприскування рослин гібереліновою кислотою, але істотне збільшення накопичення сухої маси було позначено при використанні саліцилової та аскорбінової кислот.

\section{АНОТАЦІЯ}

Дослідження проводилось у 2017-2019 рр. в умовах Правобережного Лісостепу України. Представлено результати дослідження щодо впливу обприскування органічними кислотами: саліцилова (300 ppm) гіберелінова (150 ppm) та аскорбінова кислоти (200 ppm) на рослинах часнику (Allium sativum L.). Встановлено, що розчини кислот покращують антиоксидантний стан: активність СОД, КАТ, ГвПО, ГР, ГST в оброблених листках, як правило, збільшується, активність СОД була вищою від контролю на 7,5-15,0\%, КАТ (27,4-45,9\%), ГвПО $(7,0-83,0 \%)$, ГР $(5,4-49,9 \%)$ та ГST $(14,8-41,3 \%)$. Зазначено, що вміст суми хлорофілів $a+b$ у листках значно збільшився $(2,6-10,8 \%)$. Застосування органічних кислот збільшило накопичення сухої речовини на 1,4-4,0\%. Приріст врожаю був на рівні 1,14-2,27 т/га (7,7-15,3\% порівняно 3 контролем). На вміст вітамінів групи В у зубках часнику значно впливала гіберелінова кислота, де збільшення кількості вітамінів

\footnotetext{
${ }^{70}$ Paul M.K., Pelling T., Godding O. Enhancing photosynthesis with sugar signals. Trends Plant Sci. 2001. № 6. P. 199.

${ }^{71}$ Pourtan N., Mares M., Purdy S., Quentinum N., Rue I.A., Wingler A. Interactions of bscisic acid and sugar signaling in the regulation of leaf senescence. Planta. 2004. № 219. P. 770.

${ }^{72}$ Helal F.A, Farag S.T, El-Sayed S.A. Studies on growth, yield and its components and chemical composition under effect of vitamin $\mathrm{C}$, vitamin $\mathrm{B}_{1}$, boric acid and sulphur on pea (Pisum sativum $\mathrm{L}$.) plants. J AgricSci, Mansoura Univ. 2005. № 30 (6). P. 3350.

${ }^{73}$ El-Banna E.N., Ashour S.A., Abd-El-Salam H.Z. Effect of foliar application with organic compounds on growth, yield and tubers quality of potato (Solanum tuberosum L.). J Agric Sci Mansoura Univ. 2006. № 31 (2). P. 1170.

74 Abdel-Halim S.M. Effect of some vitamins as growth regulators on growth, yield and endogenous hormones of tomato plants during winter. Egypt J Appl Sci. 1995. № 10 (12). P. 330.
} 
групи В доходило до 21,9\% порівняно 3 контролем. Використання саліцилової та аскорбінової кислот збільшило кількість вітамінів групи В на 7,6 та 8,2\% відповідно. Найбільш значне підвищення вмісту аскорбінової кислоти спостерігалось у разі обприскування рослин аскорбіновою кислотою $(+12,5 \%)$, тоді як у разі обприскування саліциловою та гібереліновою кислотами її вміст збільшився на 6,0 та 7,5\% відповідно. Отримані дані можуть бути використані для зменшення впливу абіотичних факторів на фізіологічний стан та продуктивність рослин часнику. Також дані слугуватимуть теоретичною основою для виробників 3 огляду на те, 3 якою метою вирощується продукція (реалізація у свіжому вигляді, переробка чи зберігання).

\section{ЛІТЕРАТУРА}

1. El-Shabasi M.S.S., Mohamed S.M., Mahfouz S.A. Effect of foliar spray with some amino acids on growth, yield and chemical composition of garlic plants. Proc. the $6^{\text {th }}$ Arabian Conference for Horticulture, March 20-22, Faculty of Agric., Suez Canal University, Ismailia, Egypt, 2005. P. 365-369.

2. Kowalczyk K., Zielony T. Effect of aminoplant and asahi on yield and quality of lettuce grown on rockwool. Proc. Conf. of Biostimulators in Modern Agriculture, 7-8 Febuary, Warsaw, Poland 2008. P. 124.

3. Abd El-Aal F. S., Shaheen A. M., Ahmed A. A., Mahmoud R. Effect of foliar application of urea and amino acids mixtures as antioxidants on the growth and yield and characteristics of squash. Res J Agric Biol Sci. 2010. № 6 (5). P. 583-588.

4. Ribeiro D.M., Araújo W.L., Fernie A.R., Schippers J.H.M., \& Mueller Roeber B. Translatome and metabolome effects triggered by gibberellins during rosette growth in Arabidopsis. Journal of Experimental Botany, 2012. № 63 (7). P. 2769-2786.

5. Wang Y., Gu W., Xie T., Li, L., Sun Y., Zhang H., Li, J., Wei S. Mixed compound of DCPTA and CCC increases maize yield by improving plant morphology and up-regulating photosynthetic capacity and antioxidants. Plos One, 2016. № 11 (2). P. 1-25. DOI: 10.1371/journal.pone.0149404.

6. Poprotska I.V., Kuryata V.G. Features of gas exchange and use of reserve substances in pumpkin seedlings in conditions of skoto- and photomorphogenesis under the influence of gibberellin and chlormequatchloride. Regulatory Mechanisms in Biosystems. 2017. № 8(1). P. 71-76.

7. Рогач В.В., Рогач T.I. Вплив синтетичних стимуляторів росту на морфофізіологічні характеристики та біологічну продуктивність культури картоплі. Вісник Дніпропетровського університету. Серія: Біологія, екологія. 2015. № 23 (2). Р. 221-224.

8. Mohammad N.K., Mohammad F. Effect of $\mathrm{GA}_{3}, \mathrm{~N}$ and $\mathrm{P}$ ameliorate growth, seed and fibre yield by enhancing photosynthetic capacity and 
carbonic anhydrase activity of linseed. Integrative Agriculture. 2013. № 12 (7). P. 1183-1194.

9. Muhammad I., Muhammad A. Gibberellic acid mediated induction of salt tolerance in wheat plants: Growth, ionic partitioning, photosynthesis, yield and hormonal homeostasis. Environmental and Experimental Botany. 2013. № 86. P. 76-85.

10. Yang L., Yang D., Yan X., Cui L., Wang Z., \& Yuan H. The role of gibberellins in improving the resistance of tebuconazole-coated maize seeds to chilling stress by microencapsulation. Scientific Reports. 2016. № 60. P. 1-12.

11. Saeidi-Sar S., Abbaspour H., Afshari H., \& Yaghoobi S. R. Effects of ascorbic acid and gibberellin A3 on alleviation of salt stress in common bean (Phaseolus vulgaris L.) seedlings. Acta Physiologiae Plantarum. 2013. № 35 (3). P. 667-677.

12. Yan, W., Yanhong, Y., Wenyu, Y., Taiwen, Y., Weiguo, L., \& Wang, X. Responses of root growth and nitrogen transfer metabolism to uniconazole, a growth retardant, during the seedling stage of soybean under relay strip. Communications in Soil Science and Plant Analysis Intercropping System. 2013. № 44 (22). P. 3267-3280.

13. Yan, Y., Wan, Y., Liu, W., Wang, X., Yong, T., \& Yang, W. Influence of seed treatment with uniconazole powder on soybean growth, photosynthesis, dry matter accumulation after flowering and yield in relay strip intercropping system. Plant Production Science. 2015. № 18 (3). P. 295-301.

14. Kumar S., Ghatty S., Satyanarayana J., \& Guha A. Paclobutrazol treatment as a potential strategy for higher seed and oil yield in fieldgrown Camelina sativa L. Crantz. BSK Research Notes. 2012. № 5. P. 1-13.

15. Matysiak K., Kaczmarek S. Effect of chlorocholine chloride and triazoles - tebuconazole and flusilazole on winter oilseed rape (Brassica napus var. oleifera L.) in response to the application term and sowing density. Journal of Plant Protection Research. 2013. № 53 (1). P. 79-88.

16. Khan A. L, Hamayun M., Kang S. M. Endophytic fungal association via gibberellins and indole acetic acid can improve plant growth under abiotic stress: an example of Paecilomyces formosus LHL10. BMC Microbiol. 2012. № 12:3. doi:10.1186/1471-2180-12-3.

17. Tae-Yun K., \& Jung-Hee H. Effects of hexaconazole on growth and antioxidant potential of cucumber seedlings under UV-B radiation. Journal of Environmental Science International. 2012. № 21 (12). P. 1435-1447.

18. Pavlista A. D. Influence of foliar-applied growth retardants on russet burbank potato tuber production. American Journal of Potato Research 2013. № 90. P. 395-401.

19. Zhang W., Xu F., Hua C., \& Cheng S. Effect of chlorocholine chloride on chlorophyll, photosynthesis, soluble sugar and flavonoids of Ginkgo biloba. Notulae Botanicae Horti Agrobotanici Cluj-Napoca. 2013. № 41(1). P. 97-103. 
20. Sardoei A.S., Yazdi M.R., Shshdadneghad M. Effect of cycocel on growth retardant cycocel on reducing sugar, malondialdehyde and other aldehydes of Cannabis sativa L. International Journal of Biosciences. 2014. № 4 (6). P. 127-133.

21. Sugiura D., Sawakami K., Kojim M., Sakakibara H., Terashima I., Tateno M. Roles of gibberellins and cytokinins in regulation of morphological and physiological traits in Polygonum cuspidatum responding to light and nitrogen availabilities. Functional Plant Biology. 2015. № 42(4). P. 397-409.

22. Shama M. A., Moussa S. A. M. and Abo El Fade N. I. Salicylic acid efficacy on resistance of garlic plants (Allium sativum, L.) to water salinity stress on growth, yield and its quality. Alex.Sci.Exc.J. 2016. № 37 (2). P. $165-174$.

23. Kazemi M. Foliar Application of Salicylic Acid and Calcium on Yield, Yield Component and Chemical properties of Strawberry. Bull. Env. Phar. Life Sci. 2013. № 2 (11). P. 19-23.

24. Senaratna T., Touchell D., Bunn E., and Dixon K. Acetyl salicylic acid (Aspirin) and salicylic acid induce multiple stress tolerance in bean and tomato plants. Plant Growth Regulation. 2000. № 30. P. 157-161.

25. Bardisi A. (a). Influence of vitamin $C$ and Salicylic acid foliar application on garlic plants under sandy soil condition. 1. Growth and plant chemical composition. Zagazig Journal of Agricultural Research. 2004. № 31 (4A). P. 1337-1348.

26. Bardisi A. (b). Influence of vitamin $C$ and Salicylic acid foliar application on garlic plants under sandy soil condition. 2. Yield and its Storability. Zagazig Journal of Agricultural Research. 2004. № 31 (4A). P. 1349-1360.

27. Amin A.A., Rashad S.M. and El-Abagy H.M.H. Physiological effect of indol-3-butyric acid and salicylic acid on growth, yield and chemical constituents of onion plants. Journal of Applied Sciences Research. 2007. № 3(11). P. 1554-1563.

28. El-Zohiri S.S.M. Role of the salicylic and ascorbic acid on the control of growth, flowering and yield of globe artichoke. Annals of Agricultural Science Moshtohor Journal. 2009. № 47(3). P. 393-402.

29. Bideshki A., Arvin M.J. and. Darini M. Interactive effects of Indole-3butyric acid (IBA) and salicylic acid (SA) on growth parameters, bulb yield and allicin contents of garlic (Allium sativum) under drought stress in field. International Journal of Agronomy and Plant Production. 2013. № 4 (2). P. 271-279.

30. Khadr A.A.I. Effect of salicylic acid and calcium on growth, yield and quality of garlic (Allium sativum L.) plants. M.Sc. thesis, Fac. Damanhour univ., Egypt, 2015. 110 p. 
31. Pradhan M., Tripathy P., Mandal P., Sahoo B.B., Pradhan R., Mishra S. P. and Mishra H.N. Effect of Salicylic Acid on Growth and Bulb Yield of Onion (Allium Cepa L.). International Journal of Bio-resource and Stress Management. 2016. № 7 (4). P. 960-963.

32. Prajapati S., Jain P. K. and Tiwari A. Effects of Salicylic acid (SA) and Azospirillum on growth and bulb yield of Onion (Allium cepa L.) cv. Agrifound Light Red. International Journal of Agriculture, Environment and Biotechnology. 2016. № 9 (3). P. 393-402.

33. Meena B., Aravindakshan K., Maurya I. B., Yadav I. and Singh D. Effect of Foliar Application of Salicylic Acid and Ethrel on Growth, Yield and Quality of Garlic (Allium Sativum L.) var. G282. Chemical Science Review and Letters. 2017. № 6 (21). P. 600-605.

34. Li C.X., Yang J., Wang S.C., Xia K., Li S. and Zhou X. The role of salicylic acid in the swelling of garlic (Allium statium L.) bulb. Acta. Hort. Sin. 2000. № 27. P. 220-222.

35. Rahim M.A. Control of growth and bulbing of garlic (Allium sativum L.) Ph.D. Thesis, University of London. 1988. 174 p.

36. Rahim M.A. and Forhad R. Effect of storage temperature on the initiation and development of garlic cloves (Allium sativum L.). Horticultural Science. 1988. № 37. P. 25-38.

37. Yuan L., Xu D. Q. Stimulation effect of gibberellic acid short-term treatment on the photosynthesis related to the increase in Rubisco content in broad bean and soybean. Photosynthesis Research. 2001. № 68. P. 39-47. DOI: $10.1023 / \mathrm{A}: 1011894912421$.

38. Saeidi-Sar S., Abbaspour H., Afshari H., \& Yaghoobi S. R. Effects of ascorbic acid and gibberellin A3 on alleviation of salt stress in common bean (Phaseolus vulgaris L.) seedlings. Acta Physiologiae Plantarum. 2013. № 35 (3). P. 667-677.

39. Abdel-Halim S.M. Effect of some vitamins as growth regulators on growth, yield and endogenous hormones of tomato plants during winter. Egypt J Appl Sci. 1995. № 10 (12). P. 322-334.

40. Helal F.A, Farag S.T., El-Sayed S.A. Studies on growth, yield and its components and chemical composition under effect of vitamin $\mathrm{C}$, vitamin $\mathrm{B}_{1}$, boric acid and sulphur on pea (Pisum sativum L.) plants. J AgricSci, Mansoura Univ. 2005. № 30 (6). P. 3343-3353.

41. El-Banna E.N., Ashour S.A., Abd-El-Salam H.Z. Effect of foliar application with organic compounds on growth, yield and tubers quality of potato (Solanum tuberosum L.). J Agric Sci Mansoura Univ. 2006. № 31 (2). P. 1165-1173.

42. Foyer, C.H., and Noctor, G. Ascorbate and glutathione: the heart of the redox hub. Plant Physiol. 2011. № 155. P. 2-18. doi: 10.1104/pp.110.167569. 
43. Qian H.F., Pen X.F., Han X., Ren J., Zhan K. Y., and Zhu M. The stress factor, exogenous ascorbic acid, affects plant growth and the antioxidant system in Arabidopsis thaliana. Russ. J. Plant Physiol. 2014. № 61. P. 467-475. doi: 10.1134/S1021443714040141.

44. El-Morsy A.H.A., Ezzat A.S. and Saif El-Deen U.M. Effect of some phosphorus and potassium rates and foliar spray with antioxidants on growth, yield and yield quality of garlic (Allium sativum L.). Annals of Agricultural Science Moshtohor Journal. 2010. № 48 (3). P. 27-40.

45. Gouda A.E.A.I., Gahwash M.N.M.A and Abdel- Kader A.E. Response of potato growth and yield to some stimulating compounds. J. Plant Production, Mansoura Univ. 2015. Vol. 6 (8). P. 1293-1302.

46. Petropoulos S.A., Fernandes A., Ntatsi G., Petrotos K., Barros L. and. Ferreira I.C.F.R. Nutritional Value, Chemical Characterization and Bulb Morphology of Greek Garlic Landraces. Molecules. 2018. № 23 (2). P. 319; doi: 10.3390/molecules23020319.

47. Методика дослідної справи в овочівництві і баштанництві / за ред. Г. Л. Бондаренко, К. І. Яковенко, Харків: Основа, 2001. 369 с.

48. Abd-Elkader, D.Y. Effect of Foliar Spraying with Micronutrients and Salicylic Acid on Growth, Yield and Quality of Garlic Plants. Alexandria Journal of Agricultural Sciences. 2016. № 61 (6). P. 649-658.

49. Naz H., Akram N. A., and Ashraf M. Impact of ascorbic acid on growth and some physiological attributes of cucumber (Cucumis Sativus) plants under water-deficit conditions. Pakistan Journal of Botany. 2016. № 48 (3). P. 877-883.

50. Волкодав В. В. Методика державного сортовипробування сільськогосподарських культур (картопля, овочі та баштанні культури) Київ: 2001. $101 \mathrm{c}$.

51. Методика проведення експертизи сортів рослин картоплі та груп овочевих, баштанних, пряно-смакових на придатність до поширення в Україні. Київ, 2016.

52. Методы биохимического исследования растений / за ред. А.И. Ермакова, изд. 3, дополненное и исправленное. Ленинград : Агропромиздат, $1972.456 \mathrm{c}$.

53. Beauchamp Ch., Fridovich I. Superoxide dismutase improved assays and an assay applicable to acrylamide gels. Anal. Biochem. 1971. Vol. 44 (1). P. 276-287.

54. Dhindsa R.S., Plumb-Dhindsa P., Thorpe T.A. Leaf senescence: correlated with increased levels of membrane permeability and lipid peroxidation, and decreased levels of superoxide dismutase and catalase. J. Exp. Bot. 1981. № 32: 93-101.

55. Aebi H. Catalase in vitro. Methods in Enzymol. 1984. Vol. 105. P. 121-126. 
56. Upadhyaya A., Sankhla D., Davis T. D., Sankhla N., Smith B. N. Effect of paclobutrazol on the activities of some enzymes of activated oxygen metabolism and lipid peroxidation in senescing soybean leaves. J. Plant Physiol. 1985. № 121. P. 453-461.

57. Sun J., You X.R., Li L., Peng H.X., Su W.Q., Li C.B., He Q.G., Liao F. Effects of a phospholipase D inhibitor on postharvest enzymatic browning and oxidative stress of litchi fruit. Postharvest Biol. Technol. 2011. № 62. P. 288-294.

58. Smith I.K., Vierheller T.L., Thorne C.A. Assay of glutathione reductase in crude tissue homogenates using 5,5'-dithiobis (2-nitrobenzoic acid). Anal. Biochem. 1988. № 175. P. 408-413.

59. Habig W.H., Pabst M.J., Jakoby W.B. Glutathione S-transferases. The first enzymatic step in mercapturic acid formation. J. Biol. Chem. 1974. № 246. P. 7130-7139.

60. ДСТУ 7804:2015. Продукти переробляння фруктів та овочів. Методи визначання сухих речовин або вологи. [Чинний від 2015-06-22]. Київ : Держспоживстандарт України, 2015. 19 с.

61. Food and Nutrition Board. Institute of Medicine. Dietary Reference Intakes for Thiamin, Riboflavin, Niacin, Vitamin B6, Folate, Vitamin B12, Pantothenic Acid, Biotin and Choline. Washington, DC: National Academy Press. 2000. P. 591.

62. ДСТУ 4958:2008. Фрукти, овочі та продукти їх перероблення. Метод визначення аскорбінової кислоти [Чинний від 2009-07-1]. Київ, 2009. $4 \mathrm{c}$.

63. Asada K. Production and scavenging of reactive oxygen species in chloroplasts and their functions. Plant Physiol. 2006. № 141(2). P. 391-396.

64. El-Tohamy W.A., El-Abagy H.M., El-Greadly H.M. Studies on the effect of putrescine, yeast and vitamin $\mathrm{C}$ on growth, yield and physiological responses of eggplant (Solanum melongena L.) under sandy soil conditions. Aust J Basic Appl Sci. 2008. № 2 (2). P. 296-300.

65. Paul M. K., Pelling T., Godding O. Enhancing photosynthesis with sugar signals. Trends Plant Sci. 2001. № 6. P. 197-200.

66. Pourtan N., Mares M., Purdy S., Quentinum N., Rue I.A., Wingler A. Interactions of bscisic acid and sugar signaling in the regulation of leaf senescence. Planta. 2004. № 219. P. 765-772.

\section{Information about author: Yatsenko V. V., Ph.D (Agr.),}

Lecturer at the Department of Vegetables Growing Uman National University of Horticulture 1, Instytutska str., Uman, Cherkasy region, 20300, Ukraine 